\title{
Polymerization of 1,1,2-Trimethylsilacyclobutane
}

\author{
Katsuhiko Komuro and Yusuke KaWAKAmI ${ }^{\dagger}$ \\ Graduate School of Materials Science, \\ Japan Advanced Institute of Science \& Technology, \\ Asahidai 1-1, Tatsunokuchi, Ishikawa 923-1292, Japan
}

(Received July 2, 1998)

\begin{abstract}
Polymerizations of 1,1,2-trimethylsilacyclobutane by phenyllithium and platinum complexes were studied. In polymerization by phenyllithium, the initiation reaction was nucleophilic attack of the carbanion on silicon atom of the silacyclobutane ring proved by the existence of terminal phenyl-silyl linkages in the polymer by ${ }^{1} \mathrm{H}$ NMR. Ring-opening was regioselective 1,4-. Polymers had reasonable molecular weights calculated from the molar ratio of the monomer to the initiator. Polymers with similar molecular weight were obtained even with small amounts of a platinum complex as catalyst. However, signals assignable to the olefinic protons of the polymer terminal were seen in ${ }^{1} \mathrm{H}$ NMR. Extensive chain transfer seems to have occurred. Number average molecular weight was estimated by ${ }^{1} \mathrm{H}$ NMR assuming that the polymer chain has one terminal double bond. The polymers obtained by both methods had head to tail regular structure.

KEY WORDS Silacyclobutane/Ring-Opening Polymerization/Living Polymerization/Regioselectivity / Reaction Mechanism / Chain Transfer / Isomerization /
\end{abstract}

Silicon-containing polymers have been given much attention, since they exhibit unique properties such as oxygen permeability, semiconductivity, heat-stability. ${ }^{1}$ Polycarbosilanes, whose main chain is comprised of carbon and silicon atoms, have been studied mainly as precursors for ceramic materials. ${ }^{2}$ One method to obtain polycarbosilane is the ring-opening polymerization of silacyclobutanes. Until now, there have been considerable reports on the polymerization of 1,1-dimethylsilacyclobutane (DMSB) using platinum complexes ${ }^{3-6}$ or alkyllithiums, ${ }^{7-12}$ although the reaction mechanism of polymerization has not been fully proved. For precision control of the structure of silicon-containing polymers, in addition to molecular weight, it is necessary to control the stereoregularity of the main chain.

Matsumoto reported the living nature of anionic polymerization of DMSB in $n$-hexane-tetrahydrofuran (THF) mixed solvent, ${ }^{13}$ and synthesized a block copolymer of controlled architecture. ${ }^{14}$ Although there are many reports on the control of stereochemistry of main chain by ring-opening polymerization of cyclic monomers, ${ }^{15}$ like propylene oxide and $\alpha$-amino acid NCA, there are no reports on the stereoregular polymers containing silicon atoms in the main chain. We have been interested in the control not only of the molecular weight but stereoregularity of silicon-containing polymers, and recently reported the synthesis of stereoregular poly(methylphenylsilylenetrimethylene) by polyaddition of optically active allyl-methylphenylsilane in the presence of platinum catalyst. ${ }^{16}$

Stereospecific living ring-opening polymerization of optically active silacyclobutanes is considered suitable to control molecular weight and stereoregularity of polycarbosilanes. To realize this, it is necessary to elucidate not only the living nature of the polymerization but also the stereochemical aspects of the ring-opening of the silacyclobutane ring. Since data on the polymerization of DMSB do not tell anything about the regio- and stereochemical aspects of the ring-opening, a

\footnotetext{
$\dagger$ To whom correspondence should be addressed
}

methyl group was introduced at 2-position of the ring to probe the regioselectivity in the ring-opening. As a preliminary result, we herein report the polymerization of 1,1,2-trimethylsilacyclobutane (TMSB) with alkyllithium or transition metal complex, and elucidation of the structure of the formed polymer.

\section{EXPERIMENTAL}

General

${ }^{1} \mathrm{H}$ and ${ }^{13} \mathrm{C}-\left\{{ }^{1} \mathrm{H}\right\}$ NMR, ${ }^{1} \mathrm{H}-{ }^{1} \mathrm{H}$ COSY and DEPT, ${ }^{13} \mathrm{C}-{ }^{1} \mathrm{H}$ COSY and ${ }^{29} \mathrm{Si}$ NMR spectra were recorded on Varian NMR spectrometers model Gemini 2000 $\left(300 \mathrm{MHz}\right.$ for ${ }^{1} \mathrm{H}, 75.4 \mathrm{MHz}$ for ${ }^{13} \mathrm{C}$ ), Unity Plus 500 $\left(500 \mathrm{MHz}\right.$ for ${ }^{1} \mathrm{H}, 125 \mathrm{MHz}$ for ${ }^{13} \mathrm{C}$ ), and Unity INOVA $400\left(79.5 \mathrm{MHz}\right.$ for $\left.{ }^{29} \mathrm{Si}\right)$, respectively. Chemical shifts were given in ppm relative to $\mathrm{CHCl}_{3}\left(7.26 \mathrm{ppm}\right.$ for ${ }^{1} \mathrm{H}$, $77.0 \mathrm{ppm}$ for $\left.{ }^{13} \mathrm{C}\right)$ and tetramethylsilane $(0.00 \mathrm{ppm}$ for ${ }^{29} \mathrm{Si}$ ) as internal standards in $\mathrm{CDCl}_{3}$. Mass spectra (MS) were measured on a SHIMADZU QP-5000 spectrometer. Gas chromatography analysis was made on a Yanaco GLC model G6800. Molecular weights of the polymers were estimated by a JASCO gel permeation chromatograph (GPC) model 980 at $40^{\circ} \mathrm{C}$ equipped with Shodex KF-800P (precolumn), KF-801(exclusion molecular weight, polystyrene $M_{n}=1.5 \times 10^{3}$ ), and KF-804 (exclusion molecular weight, polystyrene $\left.M_{n}=4.0 \times 10^{5}\right)$ columns using THF as an eluent $\left(1 \mathrm{~mL} \mathrm{~min}^{-1}\right)$. The molecular weight was calibrated using standard polystyrenes.

\section{Synthesis}

DMSB and TMSB were synthesized similarly to the reported procedure. ${ }^{17}$

A mixture of (1-methyl-2-propenyl)dimethylphenylsilane (1) and (2-butenyl)dimethylphenylsilane (2, trans; $\mathbf{3}$, cis) as model compounds were synthesized as previously. ${ }^{18}$ Three peaks were seen in GC-Mass chromatogram whose fragment patterns were the same. These compounds had the molecular formulae $\mathrm{C}_{4} \mathrm{H}_{7}\left(\mathrm{CH}_{3}\right)_{2} \mathrm{C}_{6} \mathrm{H}_{5} \mathrm{Si}$. $\mathbf{1}: \mathbf{2}: \mathbf{3}=42.3: 35.0: 22.7$ (estimated by GLC).

Yield: $27 \%$. bp $70-71^{\circ} \mathrm{C}(5 \mathrm{mmHg})$. The protons of 


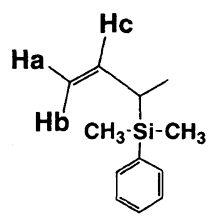

1

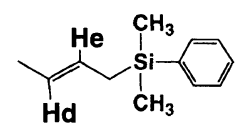

2

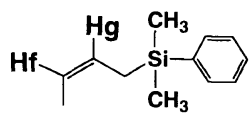

3
Figure 1. Designation of protons of the model compounds.

the model compounds are indicated in Figure 1.

${ }^{1} \mathrm{H}$ NMR $\delta 0.26\left(\mathrm{~s}, 6 \mathrm{H} \times 0.35, \mathrm{Si}\left(\mathrm{CH}_{3}\right)_{2}\right.$ of 2$), 0.27(\mathrm{~s}$, $6 \mathrm{H} \times 0.42, \mathrm{Si}\left(\mathrm{CH}_{3}\right)_{2}$ of 1$), 0.28\left(\mathrm{~s}, 6 \mathrm{H} \times 0.23, \mathrm{Si}\left(\mathrm{CH}_{3}\right)_{2}\right.$ of 3), $1.06\left(\mathrm{~d}, 3 \mathrm{H} \times 0.42, J=7.0 \mathrm{~Hz}, \mathrm{CH}_{2}=\mathrm{CHCHCH}_{3}\right.$ of 1), 1.51 (d with fine coupling, $3 \mathrm{H} \times 0.23, J=6.0 \mathrm{~Hz}$, $\mathrm{CH}_{3} \mathrm{CH}=\mathrm{CH}$ of 3$), 1.62-1.66\left(\mathrm{~m}, 3 \mathrm{H} \times 0.35, \mathrm{CH}_{3} \mathrm{CH}=\right.$ $\mathrm{CHCH}_{2}$ and $2 \mathrm{H} \times 0.35, \mathrm{CH}_{3} \mathrm{CH}=\mathrm{CHCH}_{2}$ of 2$), 1.72(\mathrm{~d}$ with fine coupling, $2 \mathrm{H} \times 0.23, J=8.0 \mathrm{~Hz}, \mathrm{CH}_{3} \mathrm{CH}=$ $\mathrm{CHCH}_{2}$ of 3$), 1.86\left(\mathrm{~m}, 1 \mathrm{H} \times 0.42, \mathrm{CH}_{2}=\mathrm{CHCHCH}_{3}\right.$ of 1), $4.81\left(\mathrm{dt}, 1 \mathrm{H} \times 0.42, J_{1}=2.0 \mathrm{~Hz}, J_{2}=17.5 \mathrm{~Hz}, H \mathrm{~b}\right)$, $4.87\left(\mathrm{dt}, \quad 1 \mathrm{H} \times 0.42, \quad J_{1}=2.0 \mathrm{~Hz}, \quad J_{2}=10.5 \mathrm{~Hz}, \quad \mathrm{Ha}\right)$, $5.25-5.32(\mathrm{~m}, 1 \mathrm{H} \times 0.35, H \mathrm{~d}), 5.35-5.47(\mathrm{~m}, 1 \mathrm{H} \times 0.42$, $H \mathrm{e}$ and $2 \mathrm{H} \times 0.23, H \mathrm{f}, \mathrm{Hg}), 5.86(\mathrm{~m}, 1 \mathrm{H} \times 0.23, \mathrm{Hc})$, $7.34-7.37,7.50-7.54\left(\mathrm{~m}, 5 \mathrm{H}\right.$, aromatic protons). ${ }^{29} \mathrm{Si}$ NMR $\delta-4.42(2,0.35),-3.65(3,0.23),-2.00(\mathbf{1}, 0.42)$. $\operatorname{MS}(m / z): 190\left(\mathrm{M}^{+}\right), 175\left(\mathrm{M}^{+}-\mathrm{CH}_{3}\right), 135\left(\mathrm{M}^{+}-\mathrm{C}_{4} \mathrm{H}_{7}\right)$, $113\left(\mathrm{M}^{+}-\mathrm{C}_{6} \mathrm{H}_{5}\right)$.

\section{Reaction of TMSB with Excess Phenyllithium}

To a solution of phenyllithium ( $1.02 \mathrm{M}$ cyclohexanediethyl ether solution, $11.2 \mathrm{~mL}, 11.4 \mathrm{mmol}$ ) in THF $(8.4 \mathrm{~mL})$ was slowly added TMSB $(1.09 \mathrm{~g}, 9.54 \mathrm{mmol})$ in THF $(4.2 \mathrm{~mL})$ for $2 \mathrm{~h}$ at $-40^{\circ} \mathrm{C}$. The reaction mixture was stirred for $2 \mathrm{~h}$ at the temperature after addition and stopped with methanol. A volatile main product (bp $86-88^{\circ} \mathrm{C} / 8 \mathrm{mmHg}$ ) was obtained by distillation under reduced pressure in $45 \%$ yield $(0.83 \mathrm{~g})$.

${ }^{1} \mathrm{H}$ NMR $\delta 0.25$ (two s, 6H, $\left.\mathrm{Si}\left(\mathrm{CH}_{3}\right)_{2}\right), 0.77(\mathrm{~m}, 1 \mathrm{H}$, $\mathrm{SiCH}), 0.90\left(\mathrm{t}, 3 \mathrm{H}, J=7.5 \mathrm{~Hz}, \mathrm{CH}_{2} \mathrm{CH}_{3}\right), 0.94(\mathrm{~d}, 3 \mathrm{H}$, $\left.J=7.0 \mathrm{~Hz}, \mathrm{CHCH}_{3}\right), 1.12,1.55\left(\mathrm{~m}, 2 \mathrm{H}, \mathrm{CH}_{3} \mathrm{CH}_{2}\right)$, 7.33-7.36, 7.49-7.51 (m, 5H, aromatic protons). ${ }^{13} \mathrm{C}$ NMR $\delta-5.00\left(\mathrm{SiCH}_{3}\right),-4.90\left(\mathrm{SiCH}_{3}\right), 13.32\left(\mathrm{CHCH}_{3}\right.$ or $\left.\mathrm{CH}_{2} \mathrm{CH}_{3}\right), 13.43\left(\mathrm{CHCH}_{3}\right.$ or $\left.\mathrm{CH}_{2} \mathrm{CH}_{3}\right), 21.15(\mathrm{SiCH})$, $24.48\left(\mathrm{CH}_{3} \mathrm{CH}_{2}\right), 127.66,128.75,134.01,139.05$ (four aromatic carbons). ${ }^{29} \mathrm{Si}$ NMR $\delta-0.30$. MS $(m / z)$ : $177\left(\mathrm{M}^{+}-\mathrm{CH}_{3}\right), 135\left(\mathrm{M}^{+}-\mathrm{C}_{4} \mathrm{H}_{9}\right), 115\left(\mathrm{M}^{+}-\mathrm{C}_{6} \mathrm{H}_{5}\right)$.

This compound was identified as 1-methylpropyldimethylphenylsilane. By analyzing the reaction mixture using GC-MS, two other products were identified.

2,3,6,6,7-Pentamethyl-2-Phenyl-2,6-Disilanonane. MS $(\mathrm{m} / z): 291\left(\mathbf{M}^{+}-\mathrm{CH}_{3}\right), 249\left(\mathbf{M}^{+}-\mathrm{C}_{4} \mathrm{H}_{9}\right), 229\left(\mathbf{M}^{+}-\right.$ $\left.\mathrm{C}_{6} \mathrm{H}_{5}\right), 135\left(\mathrm{M}^{+}-\mathrm{C}_{4} \mathrm{H}_{8} \mathrm{Si}\left(\mathrm{CH}_{3}\right)_{2} \mathrm{C}_{4} \mathrm{H}_{9}\right)$.

2,3,6,6,7,10,10,11-Octamethyl-2-Phenyl-2,6,10-Trisilatridecane. $\mathrm{MS}(\mathrm{m} / \mathrm{z}): 405\left(\mathrm{M}^{+}-\mathrm{CH}_{3}\right), 363\left(\mathrm{M}^{+}-\right.$ $\left.\mathrm{C}_{4} \mathrm{H}_{9}\right), 249\left(\mathrm{M}^{+}-\mathrm{C}_{4} \mathrm{H}_{8} \mathrm{Si}\left(\mathrm{CH}_{3}\right)_{2} \mathrm{C}_{4} \mathrm{H}_{9}\right)$.

\section{Polymerization of TMSB}

By Phenyllithium. To cyclohexane-diethyl ether solution of phenyllithium $(0.91 \mathrm{M}, 0.38 \mathrm{~mL}, 0.35 \mathrm{mmol})$ in

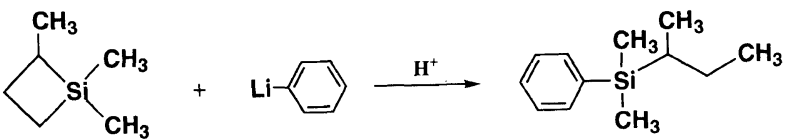

Scheme 1. Initiation reaction of TMSB by phenyllithium.

THF $(2.2 \mathrm{~mL})$, TMSB $(0.80 \mathrm{~g}, 7.00 \mathrm{mmol})$ was added at $-40^{\circ} \mathrm{C}$ under argon atmosphere, and the stirring was commenced. After $1 \mathrm{~h}$, the reaction was quenched with $1 N-\mathrm{HCl}(5 \mathrm{~mL})$, and extracted with chloroform $(15 \mathrm{~mL} \times 3)$. Polymer was obtained from chloroform solution by removing volatile materials under reduced pressure. Yield: $0.75 \mathrm{~g}(94 \%)$.

${ }^{1} \mathrm{H}$ NMR $\delta-0.08,-0.07$ (two s, $6 \mathrm{H}$, each $H_{\mathrm{E}}$ ), 0.34, $0.73\left(\right.$ two $\mathrm{m}, 2 \mathrm{H}$, each $\left.H_{\mathrm{A}}\right), 0.55\left(\mathrm{~m}, 1 \mathrm{H}, H_{\mathrm{C}}\right), 0.92(\mathrm{~d}$, $3 \mathrm{H}, J=7.2 \mathrm{~Hz}, H_{\mathrm{D}}$ ) $1.08,1.50$ (two $\mathrm{m}, 2 \mathrm{H}$, each $H_{\mathrm{B}}$ ), $7.33\left(\mathrm{~m}, 3 \times 0.05 \mathrm{H}, H_{\mathrm{o}}, H_{\mathrm{p}}\right), 7.48\left(\mathrm{~m}, 2 \times 0.05 \mathrm{H}, H_{\mathrm{m}}\right) \cdot{ }^{13} \mathrm{C}$ NMR $\delta-5.08,-5.02\left(\right.$ each $\left.C_{\mathrm{E}}\right), 12.91\left(C_{\mathrm{A}}\right), 13.63\left(C_{\mathrm{D}}\right)$, 22.26 and $22.31\left(C_{\mathrm{C}}\right), 25.91\left(C_{\mathrm{B}}\right), 127.66\left(C_{\mathrm{m}}\right), 128.73$ $\left(C_{\mathrm{p}}\right), 133.98\left(C_{\mathrm{o}}\right), 139.09\left(C_{\mathrm{i}}\right) .{ }^{29} \mathrm{Si}$ NMR $\delta 4.86$.

The assignments were made based on the data by DEPT,${ }^{13} \mathrm{C}-{ }^{1} \mathrm{H}$ COSY, ${ }^{1} \mathrm{H}-{ }^{1} \mathrm{H}$ COSY spectra. In ${ }^{1} \mathrm{H}$ NMR of the polymer, extra weak singlet at $0.25 \mathrm{ppm}$ and multiplets at 7.33 and $7.44 \mathrm{ppm}$ were observed. The peaks were assignable to terminal $\mathrm{Si}\left(\mathrm{CH}_{3}\right)_{2}$ and $\mathrm{Ph}$ protons of initiated terminal $\left[\mathrm{PhSi}\left(\mathrm{CH}_{3}\right)_{2}-\right]$, respectively.

By 1,3-Divinyl-Tetramethyldisiloxaneplatinum(0) (PtDVTMDS). To TMSB $(0.60 \mathrm{~g}, 5.25 \mathrm{mmol})$, a toluene solution of PtDVTMDS $(0.01 \mathrm{M}, 0.02 \mathrm{~mL},[\mathrm{M}] /[$ cat $]$ $\left.=3.0 \times 10^{4}\right)^{16}$ was added at $80^{\circ} \mathrm{C}$, and stirred for a given time. The resulting reaction system was dissolved in small amounts of THF and poured into large excess methanol to precipitate the polymer. Yield: $0.55 \mathrm{~g}(91 \%)$.

In ${ }^{1} \mathrm{H}$ NMR of the polymer, instead of $\mathrm{Si}\left(\mathrm{CH}_{3}\right)_{2}$ and phenyl protons of initiated terminal $\left[\mathrm{PhSi}\left(\mathrm{CH}_{3}\right)_{2}-\right]$ in anionically obtained polymer, multiplet signals at 5.2 $6.2 \mathrm{ppm}$ assignable to olefin proton $(2 \times 0.04 \mathrm{H})$, were observed besides the assignable peaks.

\section{RESULTS AND DISCUSSION}

\section{Polymerization of TMSB by Phenyllithium}

The reaction of TMSB and phenyllithium in $1: 1.2$ molar ratio gave 1-methylpropyldimethylphenylsilane, indicating that phenyllithium attacked the silicon atom of TMSB followed by 1,4-opening in the initiation reaction (Scheme 1).

Three compounds were founded in GC-MS of the volatile components of the reaction mixture in 78.1 : $19.0: 2.9$ ratio (Figure 2).

The presence of 2,3,6,6,7-pentamethyl-2-phenyl-2,6disilanonane (dimer) and 2,3,6,6,7,10,10,11-octamethyl2-phenyl-2,6,10-trisilatridecane (trimer) suggests that the propagation reaction is faster than the initiation reaction in THF.

The number average molecular weight, $M_{n}$, of the polymer obtained by phenyllithium was $3.3 \times 10^{3}$ $\left(M_{w} / M_{n}=2.7,[\mathrm{M}] /[\mathrm{I}]=20, M_{\text {calc }}=2.4 \times 10^{3}\right)$ by $\mathrm{GPC}$ analysis. When using $n$-buthyllithium or methyllithium, polymers with $M_{n}=3.0 \times 10^{3}([\mathrm{M}] /[\mathrm{I}]=20)$ and reason- 


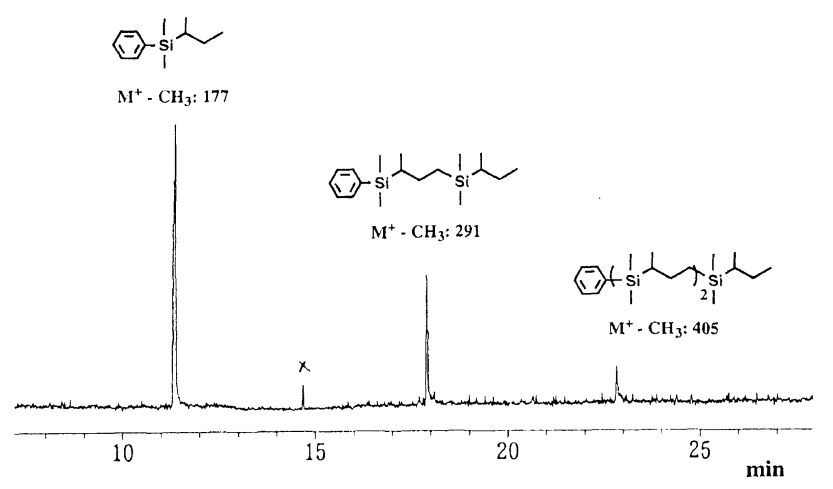

Figure 2. GC-MS chromatogram of the volatile components in the reaction of TMSB with phenyllithium in $1.0: 1.2$ molar ratio.

ably narrower molecular weight distribution $\left(M_{w} / M_{n}=\right.$ $1.4-2.0)$ were obtained. In contrast to hexane-THF mixed solvent suggested by Matsumoto, ${ }^{13,14}$ our polymerization solvent, pure THF, gave polymers of rather wide molecular weight distribution.

${ }^{1} \mathrm{H}$ and ${ }^{13} \mathrm{C}$ NMR spectra of the polymer are shown in Figure 3.

All major signals were assigned to the protons or carbons in the repeating unit, and supported by DEPT, ${ }^{1} \mathrm{H}-{ }^{1} \mathrm{H}$ COSY, ${ }^{13} \mathrm{C}-{ }^{1} \mathrm{H}$ COSY spectra. The DEPT spectrum of the polymer indicated that two $\mathrm{CH}_{3}$ carbons $\left(\mathrm{C}_{\mathrm{D}}, \mathrm{C}_{\mathrm{E}}\right)$, two $\mathrm{CH}_{2}$ carbons $\left(\mathrm{C}_{\mathrm{A}}, \mathrm{C}_{\mathrm{B}}\right)$ and one $\mathrm{CH}$ carbon $\left(C_{C}\right)$ were present in the repeating unit of the polymer. Only one sharp peak is seen at around $5.0 \mathrm{ppm}$ in the ${ }^{29} \mathrm{Si}$ spectrum. Based on these data, it was concluded that polymerization of TMSB by phenyllithium gave head to tail regular structure. In ${ }^{1} \mathrm{H}$ NMR of the polymer, the initiator fragment phenyl group was proved to be attached to the silicon atom of the polymer terminal. The degree of polymerization calculated from the ratio of phenyl proton and $\mathrm{SiCH}_{3}$ proton in the repeating unit was 20.2 . The initiator efficiency was $99 \%$ from the ratio of $[\mathrm{M}] /[\mathrm{I}]$ and $M_{n}$ estimated by ${ }^{1} \mathrm{H}$ NMR.

The correlated proton and carbon chemical shifts in the ${ }^{13} \mathrm{C}-{ }^{1} \mathrm{H}$ COSY spectrum are: ${ }^{1} \mathrm{H}-0.08$ and -0.07 ; ${ }^{13} \mathrm{C}-5.08$ and $-5.02\left(\mathrm{SiCH}_{3}\right),{ }^{1} \mathrm{H} 0.34$ and $0.73 ;{ }^{13} \mathrm{C}$ $12.91\left(\mathrm{SiCH}_{2}\right),{ }^{1} \mathrm{H} 0.55 ;{ }^{13} \mathrm{C} 22.26$ and $22.31(\mathrm{SiCH}),{ }^{1} \mathrm{H}$ $0.92 ;{ }^{13} \mathrm{C} 13.63\left(\mathrm{CHCH}_{3}\right),{ }^{1} \mathrm{H} 1.08$ and $1.50 ;{ }^{13} \mathrm{C} 25.91$ $\left(\mathrm{SiCH}_{2} \mathrm{CH}_{2}\right)$.

According to the enlarged spectra, the $\mathrm{SiCH}_{3}$ protons $\left(H_{\mathrm{E}}\right)$ and carbons $\left(C_{\mathrm{E}}\right)$ are split into two singlets. The two $\mathrm{CH}_{2}$ protons of the repeating unit $\left(H_{\mathrm{A}}\right.$ and $\left.H_{\mathrm{B}}\right)$ are also split into two multiplets. There is the possibility that the splittings are caused by diad tacticity. However, if such splitting is caused by diad tacticity, the only one pair of signals for each repeating methylene protons strongly suggests the polymer being isotactic, which should not be the case for the polymerization of racemic monomer. These splittings are considered enantiotopic by the presence of neighboring asymmetric center $\left(C_{\mathrm{C}}\right)$. The $\mathrm{SiCHCH}_{3}$ carbon $\left(C_{C}\right)$ also split into two singlets of equal intensity. This splitting might be caused by triad tacticity, but details are not clear at present, since this carbon should split into three singlets instead of two, if this carbon reflects the triad tacticity.
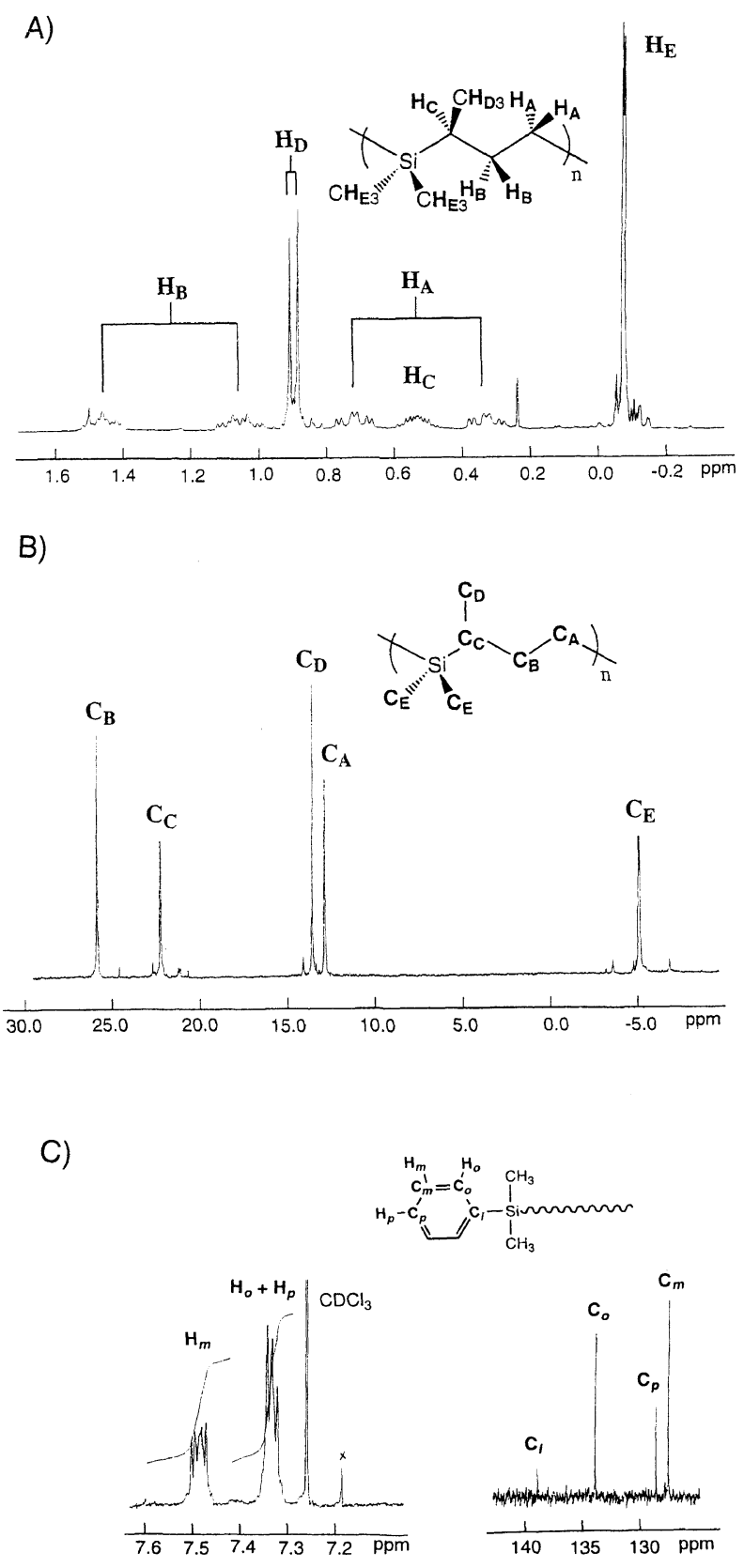

Figure 3. NMR spectra of poly(TMSB) produced by phenyllithium, A) ${ }^{1} \mathrm{H}$, main chain; B) ${ }^{13} \mathrm{C}$, main chain, C) ${ }^{1} \mathrm{H}$ and ${ }^{13} \mathrm{C}$, terminal aromatic region (at room temperature in $\mathrm{CDCl}_{3}:{ }^{1} \mathrm{H}, 300 \mathrm{MHz} ;{ }^{13} \mathrm{C}$, 75.4 MHz).

\section{Polymerization by Transition Metal Complex}

The results of polymerization of dimethylsilacyclobutane derivatives using transition metal complexes are summarized in Table I.

The fate of the monomer was followed by ${ }^{1} \mathrm{H}$ NMR for determination of conversion. The number average molecular weights of the polymer were $3.7-4.7 \times 10^{3}$ $\left(M_{w} / M_{n}=1.5-1.6\right)$. The polymerization of DMSB using platinum complex gives high molecular weight polymer, ${ }^{19}$ for example, $M_{n}=1.1 \times 10^{5}$ with PtDVTMDS which were also included in the Table. In contrast to the polymerization of DMSB, lower molecular weight materials were formed in the polymerization of TMSB. This suggests the existence of chain transfer reaction, although, molecular weight distribution is reasonably narrow. The rhodium complex did not show activity even 
Table I. Polymerization of silacyclobutanes by transition metal catalysts ${ }^{\mathrm{a}}$

\begin{tabular}{|c|c|c|c|c|c|c|c|}
\hline Run & Monomer & Cat & Conv. $/ \%^{\mathrm{b}}$ & $M_{n}^{\mathrm{c}} / 10^{3}$ & $M_{w} / M_{n}^{\mathrm{c}}$ & $M_{n, \mathrm{NMR}} \mathrm{b} / 10^{3}$ & Yield $/ \%$ \\
\hline 1 & TMSB & PtDVTMDS & Quant. & 3.7 & 1.5 & 2.8 & 91 \\
\hline 2 & & PtDVTMDS $^{d}$ & 0 & - & - & - & - \\
\hline 3 & & $\mathrm{H}_{2} \mathrm{PtCl}_{6}$ & Quant. & 4.7 & 1.6 & 3.3 & 95 \\
\hline 4 & & $\mathrm{Ph}\left(\mathrm{PPh}_{3}\right)_{3} \mathrm{Cl}$ & 0 & - & - & - & - \\
\hline 5 & DMSB & PtDVTMDS ${ }^{e}$ & Quant. & 110 & 1.3 & - & 94 \\
\hline
\end{tabular}

${ }^{\mathrm{a}}$ In bulk, for $17 \mathrm{~h}$, at $80^{\circ} \mathrm{C},[\mathrm{M}] /[\mathrm{Cat}]=3.0 \times 10^{4} .{ }^{\mathrm{b}}$ Estimated by ${ }^{1} \mathrm{H}$ NMR. $\quad{ }^{c}$ Estimated by GPC using standard polystyrene. $\quad{ }^{\mathrm{d}}$ At room temperarure. ${ }^{\mathrm{e}}$ In toluene, $[\mathrm{M}]=5.0 \mathrm{M}$, for $30 \mathrm{~min}$.

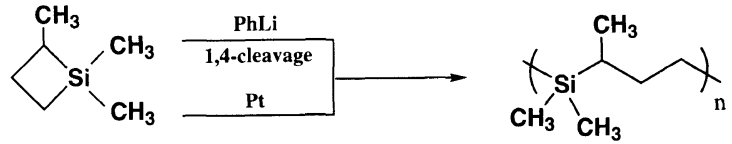

Scheme 2. Head to tail regular structure of poly(TMSB) by phenyllithium and Pt complex.

\section{at $80^{\circ} \mathrm{C}$}

The major peaks of ${ }^{29} \mathrm{Si},{ }^{13} \mathrm{C},{ }^{1} \mathrm{H}$ NMR spectra were the same as those of the polymers obtained by phenyllithium. The polymers obtained by two different procedures had the same head to tail regular structure (Scheme 2).

In the ${ }^{1} \mathrm{H}$ NMR spectrum, multiplets at $5.20-5.85$ ppm assignable to the olefin protons were seen (Figure 4B). The olefinic protons consisted of basically three protons reflecting the structure at $5.21-5.46,5.52$ 5.53 (two singlets), and $5.56-5.86 \mathrm{ppm}$ in the ratio of $63.4: 2.6: 18.0$. To elucidate the origin and structures of the double bonds formed by platinum complexes, which must have strong correlation with the reaction mechanism, the structures of the double bonds were studied by comparison with model compounds.

The majority of the olefinic protons of the polymer terminal appeared at quite similar positions with inner olefinic protons of the model compounds $(2,3)$ (Figure $4 \mathrm{~A})$ at $5.21-5.46 \mathrm{ppm}$. These olefinic protons are considered to be the inner type 6 in Scheme 3 (two protons). The singlets at 5.52 and 5.55 are tentatively assigned to olefinic proton of cis and trans form of the terminal type 5 (one proton each). The signals at 5.57 and $5.93(J=18.0 \mathrm{~Hz})$, and multiplets at $5.71-5.86$ are assignable to terminal vinyl protons of the type 4 .

The polymer by anionic procedure did not show such signals. The presence of the inner olefinic signals suggests that these olefinic bonds were formed by chain transfer reaction in the polymerization through the $\beta$-elimination of the propagating end, and that isomerization of the terminal olefin to inner olefin might have occurred.

Lappert reported that the reaction of TMSB with $\left[\mathrm{Fe}_{2}(\mathrm{CO})_{9}\right]$ gave 1-ferra-1,1,1,1-tetracarbonyl-2,2,3-trimethyl-2-silacyclopentane by steric hindrance. ${ }^{20}$ Tanaka reported that the polymerization of silacyclobutane proceeded through 1-platina-2-silacyclopentane intermediate. ${ }^{19}$ Although it is not clear which bond of 1,2- or 1,4- is cleaved in the polymerization of TMSB by platinum catalyst, the silacyclobutane ring must open at 1,2- or 1,4-bond selectively to give head-tail controlled polymer structure. It may be reasonable to assume 1-platina-2,2,3-trimethyl-2-silacyclopentane is formed as the intermediate which gives growing end through

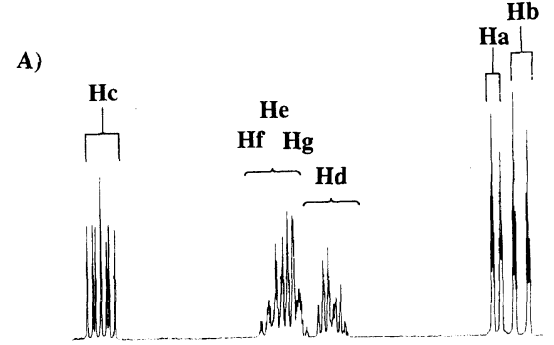

B)

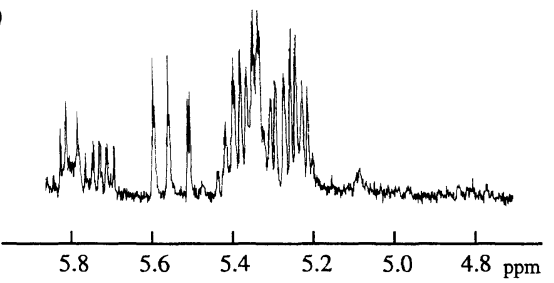

Figure 4. Olefinic region of ${ }^{1} \mathrm{H}$ NMR spectra $\mathrm{A}$ ) mixture of $\mathbf{1}, \mathbf{2}$, and 3, B) poly(TMSB) by $\mathrm{H}_{2} \mathrm{PtCl}_{6}(500 \mathrm{MHz}$, at room temperature in $\left.\mathrm{CDCl}_{3}\right)$.

1,4-cleavage of the ring. The polymerization is considered to proceed according to following mechanism: 1) oxidative addition of TMSB to the Pt complex to form platinasilacyclopentane ring (slow), followed by ringopening (fast) (initiation reaction), 2) repeated formation of platinasilacyclopentane ring and ring-opening (propagation reaction), 3) elimination of platinum hydride (chain transfer reaction) to give the structures 4 and 6. Isomerization from $\mathbf{4}$ to $\mathbf{5}$ may occur thermally and catalytically. When the insertion of TMSB to the growing end occurs in the 1,2-mode, the formed propagating end might be less reactive than that formed via 1,4-addition because of the steric factor, and elimination of platinum hydride which gives inner olefinic terminal 6 might be preferred over propagation reaction. The major chain transfer reaction may occur by this reaction path, and the butenyl terminal would be produced mainly in the polymer.

From the ratio of terminal olefinic protons $(2 \mathrm{H}$ for $\mathbf{6}$, $1 \mathrm{H}$ for 5 , and $3 \mathrm{H}$ for 4$)$ ) and $\mathrm{Si}\left(\mathrm{CH}_{3}\right)_{2}(6 \mathrm{H})$, the degree of polymerization was estimated (Table I). Number average molecular weights estimated by ${ }^{1} \mathrm{H}$ NMR were considerably smaller $(25-30 \%)$ than by GPC.

\section{CONCLUSIONS}

Polymerizations of TMSB were carried out with phenyllithium and Pt complexes. Polymers had controlled head to tail structure. 1,4-Bond of the monomer was selectively cleaved in the anionic polymerization by phenyllithium. In polymerization by $\mathrm{Pt}$ complexes, 


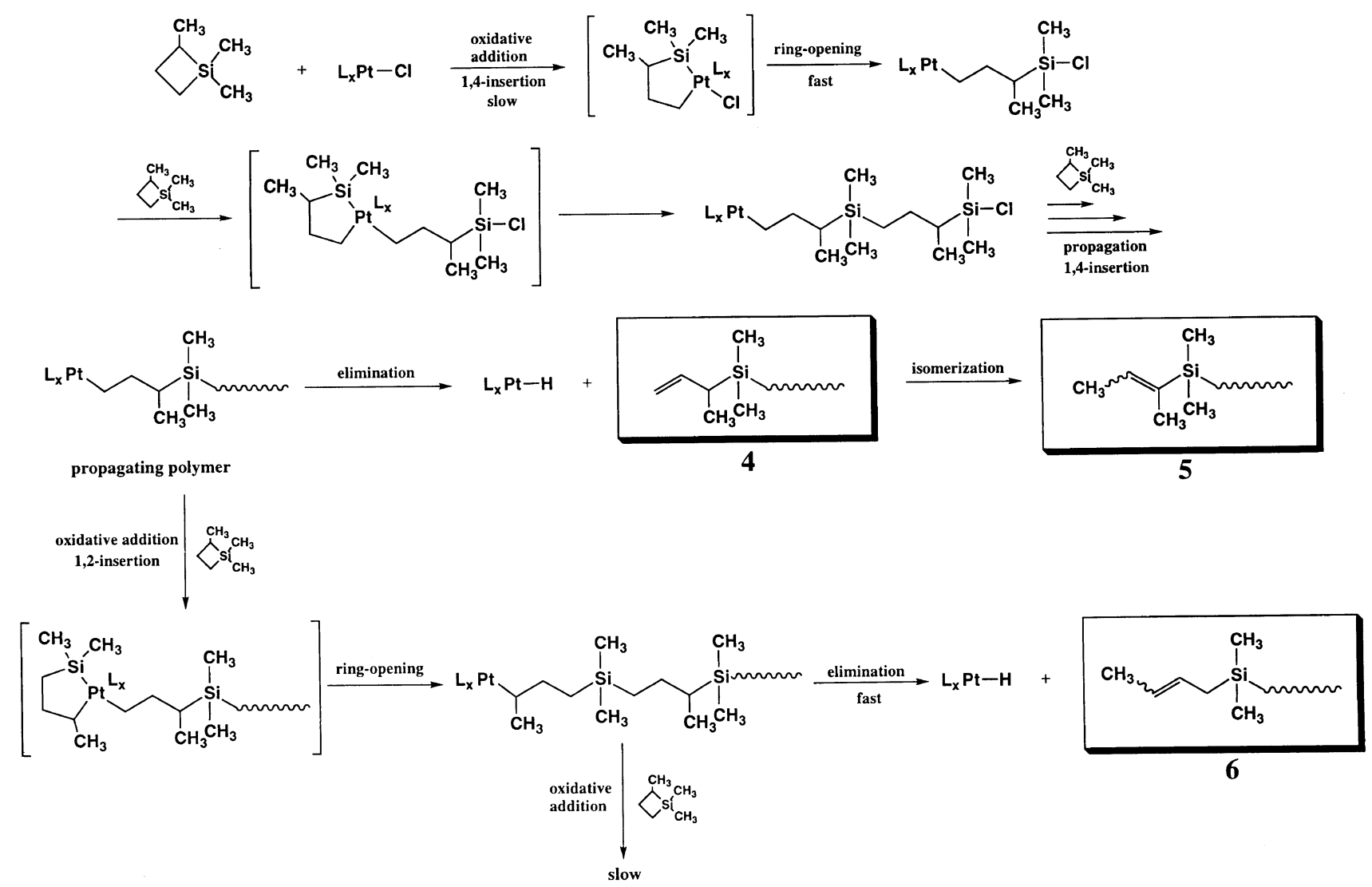

Scheme 3. Polymerization mechanism by the Pt complex.

propagation reaction is the selective oxidative addition of the monomer to the $\mathrm{Pt}$ complex in either 1,2- or 1,4-bond. Frequent chain transfer reaction occurred through 1,2-insertion to give 2-butenyl terminal.

Acknowledgments. The authors are grateful to ShinEtsu Chemicals Co., Ltd. for generous donation of organosilicon compounds. This work was partially supported by Grants-in-Aid for Scientific Research (08455438), for Scientific Research in Priority Areas (10133220), and for Scientific Research in Priority Areas, New Polymers and Their Nano-Organized Systems (10126222) from the Ministry of Education, Science, Sports and Culture of Japan.

\section{REFERENCES}

1. W. R. Hertler and H. R. Kricheldorf, Ed., "Silicon in Polymer Synthesis," Springer-Verlag, Heidelberg, 1996.

2. M. Birot, J.-P. Pillot, and J. Dunoguès, Chem. Rev., 95, 1443 (1995).

3. N. S. Nametkin, V. M. Vdovin, and P. L. Grinberg, Izv. Akad. Nauk SSSR Ser. Khim., 1133 (1964).

4. D. R. Weyenberg and L. E. Nelson, J. Org. Chem., 30, 2618 (1965).

5. C. S. Cundy, C. Eaborn, and M. F. Lappert, J. Organomet. Chem., 44, 291 (1972).

6. V. A. Poletaev, V. M. Vdovin, and N. S. Nametkin, Dokl. Akad.
Nauk SSSR, 208, 1112 (1973).

7. N. S. Nametkin, V. M. Vdovin, and V. I. Zav'yalov, Izv. Akad. Nauk SSSR Ser. Khim., 203 (1964).

8. N. S. Nametkin, N. B. Bespalova, N. V. Ushakov, and V. M. Vdovin, Dokl. Akad. Nauk SSSR, 209, 621 (1964).

9. N. S. Nametkin, V. M. Vdovin, V. A. Poletaev, and V. I. Zav'yalov, Dokl. Akad. Nauk SSSR, 175, 1068 (1967).

10. C. X. Liao and W. P. Weber, Polym. Bull., 28, 281 (1992).

11. C. Xiugao and W. P. Weber, Macromolecules, 25, 1639 (1992).

12. M. Theuring and W. P. Weber, Polym. Bull., 28, 17 (1992).

13. K. Matsumoto and H. Yamaoka, Macromolecules, 28, 7029 (1995).

14. K. Matsumoto, H. Shimazu, M. Deguchi, and H. Yamaoka, J. Polym. Sci., Part A, Polym. Chem. Ed., 35, 3207 (1997).

15. Propylene oxide: T. Tsuruta, and Y. Kawakami, "Anionic Ring-opening Polymerization: Stereospecificity for Epoxides, Episulfides and Lactones,' in 'Comprehensive Polymer Science,' Vol. 3, Pergamon, Oxford, 1989, p 489,

$\alpha$-Amino Acid NCA: H. R. Kricheldorf, 'Anionic Ring-opening Polymerization: N-Carboxyanhydrides,' in "Comprehensive Polymer Science," Vol. 3, Pergamon, Oxford, 1989, p 531.

16. Y. Kawakami, K. Takeyama, K. Komuro, and O. Ooi, Macromolecules, 31, 551 (1998).

17. J. Dubac, P. Mazerolles, M. Lesbre, and M. Joly, J. Organomet. Chem., 25, 367 (1970).

18. H. Sakurai, Y. Kudo, and H. Miyoshi, Bull. Chem. Soc., Jpn., 49, 1433 (1976)

19. H. Yamashita, M. Tanaka, and K. Honda, J. Am. Chem. Soc., 117, 8873 (1995).

20. C. S. Cundy, M. F. Lappert, F. Michael, J. Dubac, and P. Mazerolles, J. Chem. Soc., Dalton Trans., 10, 910 (1976). 